In Rigby v. Hewitt (1850) 5 Ex. 240, Pollock, C.B., said: "I am, however, disposed not quite to acquiesce to the full extent in the proposition that a person is responsible for all the possible consequences of his negligence. I wish to guard against laying down the proposition so universally; but of this I am quite clear, that every person who does a wrong is at least responsible for all the mischievous consequences that may reasonably be expected to result under ordinary circumstances from such misconduct."

In Greenland v. Chaplin (1855) 5 Ex. 243, he said: "I am desirous that it may be understood that $I$ entertain considerable doubt whether a person who is guilty of negligence is responsible for all the consequences which may under any circumstances arise, and in respect of mischief which could by no possibility have been foreseen and which no reasonable person would have anticipated."

A contrary view was taken by Channell, B., and Blackburn, J., in Smith v. London and South Western Railway Co., L. R. 6 C. P. 21. Channell, B., said: "When there is no direct evidence of negligence, the question what a reasonable man might foresee is of importance in considering the question whether there is evidence for the jury of negligence or not ... but when it has been once determined that there is evidence of negligence, the person guilty of it is equally liable for its consequences, whether he could have foreseen them or not."

Blackburn, J., said : "What the defendants might reasonably anticipate is only material with reference to the question whether the defendants were negligent or not and cannot alter their liability if they were guilty of negligence."

The view taken by Pollock, C.B., and that taken by Channell, B., and Blackburn, J., may be summed up respectively as follows: According to the former the defendant is responsible only for the consequences resulting from the act, assuming it to be negligent, which may reasonably be expected to result from such negligence. According to the latter the consequences which may reasonably be expected to result from a particular act are material only in reference to the question whether the act is or is not a negligent act. Once negligence is established the defendant is responsible for all damage which results directly from the act.

The latter is the view which has now obtained judicial recognition. It was adopted by Sir Samuel Evans in H.M.S. London [1914] P. 72, 76, and by Lord Sumner in Weld-Blundell v. Stephen [1920] A. C. 983, 984, and it was also adopted by all three of the Lords Justices in the case under consideration, Lord Justice Warrington expressly stating that in his opinion the law on the point was correctly stated in the late Mr. Beven's book on Negligence, in which the same view is adopted.

R. B.

TORT-Conversion.

Murdoch \& Co. v. Wood. [1921] W. N. $299 ; 38$ T. L. R. 23.

Appeal from Marylebone County Court. On November 8, 1919, the plaintiffs and one Cohen entered into \& hire-purchase agreement by which Cohen hired a piano. By the terms of the agreement the property in the 
piano was not to pass to Cohen until all the instalments had been paid. Also Cohen was to keep the piano in his own custody, and "if the hirer do not duly observe this agreement, the owner may, without any formal notice, put an end to the hiring and retake possession." In June, 1920, the piano was sold by Cohen to the defendant, who believed that it was Cohen's property. At that time no instalments were in arrear.

In October, 1920, Cohen borrowed the piano, which was delivered at his house. Subsequently Cohen informed the defendant that he only had the piano on a hire-purchase agreement. Thereupon the defendant refused to have any more dealings with it and Cohen promised to pay back to him the purchase money of $£ 55$.

Cohen sold the piano to somebody else and in December, 1920, left England without paying the defendant. All the instalments due up to then had been paid by Cohen, but a balance of $£ 12$ remained due. The plaintiffs did not know of the above dealings until December, 1920.

They claimed damages against the defendant for the conversion of the piano and they got judgment in the County Court for $£ 55$. The defendant appealed and the Court allowed the appeal.

Horridge, J., in delivering the judgment of the Court, said that if the plaintiffs were entitled to possession of the piano when the defendant took it over in June, then undoubtedly the acts of the defendant amounted to conversion. It was contended that Cohen repudiated the contract by his wrongful act in selling the piano. "But one party could not effectually repudiate without an acceptance of the repudiation by the other party[Johnstone v. Milling (1861) 16 Q. B. D. 460]-and the plaintiffs, being unaware of the transaction, never accepted the alleged repudiation."

In Whiteley, Lim. v. Hilt [1918] 2 K. B. 808, the Court of Appeal, reversing the judgment of the Divisional Court, had held that a sale by the hirer did not amount to a repudiation. Also, in this case, Cohen continued to pay instalments as late as December, 1920. Therefore, there could not have been any repudiation determining the rights of the hirer.

Owing to the breach of the agreement by Cohen the plaintiffs were entitled to put an end to the hiring and retake possession. They did neither owing to ignorance of the transaction. Consequently they were never in the position of being entitled to retake possession of the piano. Until the hirer's interest determined trover would not lie. (Gordon v. Harper (1786)). Consequently, as Cohen's interest still existed, there was no conversion by the defendant and the appeal must be allowed.

H. C. W. T.

[EdTon's Note.-

It is difficult at first sight to understand why the purchase by the defendant from Cohen did not constitute conversion in the defendant. The Divisional Court did not apparently consider the point that it was a breach of the hire-purchase agreement for Cohen to let the piano go out of his possession. It is apparent from the decision of the Court of Appeal in Whiteley, Lim. v. Bilt (supra) that there was no conversion on the facts of that case, which are not precisely the same; for it did not necessarily follow there that the sale of a chattel hired by a hirer conveyed no title whatever. Murdoch v. Wood has been reversed on appeal, the Court of Appeal holding that a Divisional Court has no jurisdiction to reverse a decision of the County Court upon grounds which were not raised before the County Court Judge (38 T. L. R. 393). The Master of the Rolls considered it right to say that the case ought not to be cited as 
an authority in any subsequent case. He expressly reserved the question as to whether the decision of the Divisional Court was right or wrong.

E. C. S. W.]

\section{Tort-Conversion-Nature of INFringement.}

Van Oppem \& Co., Lim. v. Tredegars, Lim. 37 T. L. R. 504.

The plaintiffs as carriers mistakenly delivered certain goods to $M$. While the goods were in M.'s warehouse, B., the agent of the defendants, saw them, claimed them as the property of his principals and purported to sell them to M., who paid the defendants for them. [It does not appear that the defendants were consignors of the goods, or that the claim of their agent thereto was a rightful one.]

Plaintiffs sued for conversion, claiming full value of the goods.

It was argued for the defendants, on what amounted to a demurrer, that the facts did not disclose anything to support a cause of action, inasmuch as (1) the plaintiffs as bailees had parted with possession by their delivery to M., and could not therefore maintain trover. (2) The defendants had not in any way physically interfered with the goods or with the documents of title thereto; and in the absence of such physical interference, conversion could not be maintained.

Darling, J., gave judgment for the plaintifis. He held that even if the plaintiffs could not sue in trover, they had a good cause of action on the case, and since the Judicature Acts this could make no difference. As to (1), although by virtue of the mistaken delivery $M$. had physical custody of the goods, constructive possession remained in the plaintiffs. MI. held the goods merely as their agent. As to (2), actual physical interference with the goods is not essential to conversion. The act of the defendants in purporting to sell the goods was an infringement of the plaintiff' rights sufficient to constitute conversion.

The nature of the "infringement" in this case consisted of a wrongful disposal of goods without any taking possession of them. The decision thus goes further than that in Hiort v. Bott, L. R. 9 Ex. 86, where there was at least an interference with the document of title.

It would appear that in developing a test of conversion, the Courts show an increasing tendency to look to the result of the act of a defendant on the title of a plaintiff, rather than to the nature of the act of the defendant.

A wrongful act whereby a plaintiff, being entitled to the possession of goods, is deprived of that right suffices to constitute conversion.

H. E. S.

Negligence-Master and Servant-Defective Apparatus Supplied by Master-Effect of KNowledge on Part of Master or of Servant.

Baker v. .Tames Bros. [1921] 2 K. B. $675 ; 37$ T. L. R. 591

THIs case is of importance from the disapproval expressed by McCardie, J., of Griffiths v. London and St. Katherine's Dock Co., 13 Q. B. D. 259, a case which, though undoubtedly anomalous and con- 